\title{
Argimütoloogia kui Mati Undi poeetika lähtekoht
}

\author{
INDREK OJAM
}

\section{Realismi ja müüdi probleem Mati Undi retseptsioonis}

Praegu võib suure kindlusega väita, et Mati Undi looming on saavutanud keskse koha Teise maailmasõja järgse kodu-eesti proosakirjanduse pildis. Samuti kõnetavad tema teosed uute lugejate põlvkondi, mida näitavad viimaste aastate üliõpilastööd (Remmel 2015; Berg 2015; Puudersell 2019), mälestusteraamat (Kesküla 2008), interdistsiplinaarne artiklikogumik (Sarapik, Viires 2010) ja Undi loomingu erinevaid taustu täpsustavad artiklid (vt Vaino 2019; Puudersell 2017). Undi jätkuv ajakohasus ja püsiv huvi tema proosateoste ${ }^{1}$ vastu on seda tähelepanuväärsem, et tema tekstid on ilmunud üle pika ajavahemiku, alates Hruštšovi sula viimastest aastatest, läbi hilissotsialismi perioodi kuni poliitiliste murrangute ja taasiseseisvunud Eesti esimese kümnendini. Nii nende teoste ühiskondlik kontekst kui ka tekste tõlgendava kriitika printsiipide pidev teisenemine on ühest küljest Undi loomingu vastuvõttu toonud eri teemasid ja hääli. Teisest küljest on aga Undi andele osaks langenud peaaegu üksmeelne heakskiit ja tema poeetika analüüs on keerelnud aina samade motiivide ja märksõnade ümber.

Neid märksõnu koondab Undi tekstide hämmastava ajakohasuse ja realistlikkuse mulje. Maie Kalda (1976 [1969]: 68) märkas juba lühiromaani „Mõrv hotellis” (1969) juures, et Undi hoolikalt komponeeritud väike lõik hotelli prügikasti sisu loeteluga mõjub lugemisel kogu tsivilisatsiooni saasta mikromudelina. Madis Kõiv (2005a: 496-497) nimetas oma 1980. aastal kirjutatud essees Undi jäljendamisvõimet üliinimlikuks, võimeliseks isegi tulevikku ette näha. Hando Runneli (1980: 115) vaatenurgast on Unt eelkõige moekirjanik, kel on tugev vaist kõikvõimalike uute ja oluliste ideede, iidolite ja isikute äratabamiseks. Seda iseäralikku annet ülistavalt mõjub ka Jaan Unduski (2016 [1986]: 778) määratlus Undist kui parimast 1960-ndate ja 1970-ndate „triviaalpsühhograafist”, kes suudab parasjagu kultuuris lenduvaid meeleolusid „nutmaajava täpsusega” tabada. Tõepoolest, Undi varasema loomingu puhul on jutuks olnud „ajastu keskmes” asumine, mistõttu on tema retseptsiooni murdepunktiks kujunenud Tiit Hennoste (2003 [1993]) ja Unduski (2016 [1986]: 779) tõdemus, et alates 1980. aastatest ei käi Undi loodud tekst enam ajastuga samas rütmis, tema looming on muutunud perifeersemaks ja postmodernistlikuks (sama aega on nimetatud ka postmodernse ühiskondliku taju sünniajaks).

Kõiki neid tähelepanekuid, iseäranis loomingu „ajastu keskmes” paiknemise kohta, iseloomustab seostumine realistliku kujutamise ehk mimesise problemaati-

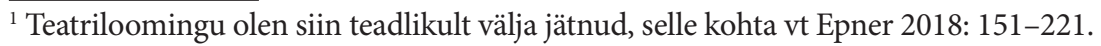


kaga. Küsimuse all on olnud Undi edukus ühiselt äratuntavate tundestruktuuride (vt Williams 1977) ${ }^{2}$ kujutamisel. Kasutan siin edaspidi terminit realistlik kujutamine või kirjutamine nii, nagu see esineb Erich Auerbachi teoses „Mimesis” (1946, e k 2012): see tähendab lähtumist metodoloogilisest eeldusest, et kuigi realismi mõistet ei ole kunagi rahuldava täpsusega määratletud, on mingisugune realistliku kujutamise idee kirjanduse ajaloolisel mõistmisel möödapääsmatu ja vaikimisi omaks võetud. Kirjandusliku realismi idee on nii lääne kultuuri historistliku maailmatunnetuse lahutamatu osa kui ka uutele ajaloolistele muutustele alluv nähtus. ${ }^{3}$ Kirjanduse keele kujundliku ja ajaloolise olemuse tõttu on realistlik kirjutus alati moodustumas ja ümber kujunemas, asudes nii erinevate realistlike žanrikonventsioonide kui ka allegoorilisemate (ehk alati mingisuguse teise kõnele viitavate) või iroonilisemate (oma kujutamisambitsiooni tühistavate) tähenduste kujunemise vahelises tasakaalupunktis. Ükski kirjandustekst ei ole muutumatult realistlik, kuid realistlike lugemisviiside jälgimine retseptsioonis annab hädavajalikku teavet kirjanduse ajaloolise konteksti ja seega selle tähenduse kohta. Realismi mõiste määratlemisel ei saa mööda ka kvantitatiivsest aspektist: reaalsus kui totaalsus on alati paljune, see moodustub mitmetest osadest. Ka fragmentaarne kirjutus võib tekitada realismi efekti, ent fragment üksi ei ole realistlik kirjandus. Just t o t a a ls u s ehk võime luua millegi endast suurema terviklik mudel (või vähemalt selline ambitsioon) on realismi mõiste tihti varjatud, kuid vajalik komponent, mille põhjal me lugejatena tajume mõne teose realismiambitsiooni (vt ka Jameson 2007 [1990]: 244). Realistlik efekt võib kirjanduses ilmneda mitte ainult võimalikult usutavate sündmuste põhjuslikul kujutamisel, millest moodustub teose narratiivne selgroog, vaid ka rohkem kirjeldusi kasutaval, stseenilisel viisil (selle eristuse ja kogu realismi problemaatika kohta vt Ojam, Tomberg 2016). Realistliku mulje võivad tekstis tagada nii sündmused kui ka tumm, aga tuttav asjade ja kehaliste afektide vald. Nende määratlustega püüan juhtida tähelepanu igasuguse realistliku kujutamise muutuvale sotsiaal-ontoloogilisele allikale ning vältida alati ebaõnnestuvaid katseid defineerida realistlikkust „maise” või „lihtsa” kirjutusena. ${ }^{4}$ Kirjanduses loodud reaalsuses ei ole kunagi midagi loomulikku.

\footnotetext{
${ }^{2}$ Viitan siin teadlikult Raymond Williamsi loodud mõistele: tundestruktuurid (ingl structures of feeling) on kunsti vormis esinevad hüpoteesid uute, alles ilmnevate sotsiaalsete reaalsuste kohta. Sõna struktuur, mida kasutab Undi teoste realistliku mõju kohta ka nt Undusk (2016 [1986]: 778), viitab selles mõistes kunstiloomingu näiliselt väga spontaansete elementide universaalsele ja süsteemsele olemusele. Tundestruktuurid kunstiteostes vastavad oma ajastu ühiskondlikele kokkulepetele ja konventsioonidele ning just selle seose mõtestamise tõttu on võimalik kirjandusliku realismi ja selle muutumise üle viljakalt vaielda.

${ }^{3}$ Realismi mõiste vastuolulisus või mitmeti mõistetavus sisaldub ka Auerbachi „Mimesises”, kus see omandab kaks erinevat tähendusvarjundit: ühelt poolt igasugune tõsine kirjanduses loodud tegelikkusekujutus, mille varieerumist vaatleb Auerbach alates Vana Testamendi ja Homerose tekstidest kuni XX sajandini; ja teiselt poolt XIX sajandi hakul sündinud spetsiifiliselt ajalooline maailmatunnetus, mille keskmes on aina jätkuv ühiskondlik emantsipatsioon, mille toimel žanripiirid lahustuvad ning kirjanduslik kujutamine jõuab ka varem madalateks peetud teemade, isikute ja ruumideni (Auerbach 2012: 685-687).

${ }^{4}$ Hayden White'i (1999) eeskujul, kes peab samuti Auerbachi teosega dialoogi, võiks realismi erinevaid ilminguid nimetada ka mimeesiefektideks, mida siinkohal pole võimaliku segaduse loomise kartuses tehtud.
} 
Lähtudes neist eeldustest, on käesoleva artikli eesmärk süveneda Mati Undi teostele niivõrd suure veenvuse ja realistlikkuse taganud poeetilisse võttesse, mida nimetan Undi samanimelise teostesarja (Unt 1993, 1996, 2003) pealkirjade eeskujul lihtsalt argimütoloogiaks. Minu tees on, et argimütoloogiline poeetika seisneb igapäevase müüdilise mõtlemise esile toomises ja rakendamises realistliku mulje loomiseks. Undi kirjanikukreedos on kindlasti oluline retseptsiooniski korduv märksõna mäng, kuid mängu mõiste kaldub liiga rutakalt ja enesestmõistetavalt asetuma teksti ja representatsiooni probleemide asemele (nt Puudersell 2017; Vaino 2019: 119-138). Undi tekstide suhe ajaloolise „toormaterjaliga” ja sellest tulenev realistlik mõju vajab täiendavat selgitamist, enne kui mõistetele, nagu mäng, kindlat tähendust omistada. Soovin järgnevaga näidata, et Undi loomingu isepärane realistlikkus põhineb nn argimüüdilise tuumstseeni pideval otsimisel ja sõnastamisel, kui mõista sõna argimüüt ideoloogia tähenduses: kõikvõimalikud kultuuris ringlevad reaalsust müstifitseerivad narratiivid (ideoloogia mõiste juures lähtun Roland Barthes'i käsitlusest teoses „Mütoloogiad” (1957, e k 2004), millest pikemalt allpool). Undi hilisemad lühikirjutised, mis ongi pealkirjastatud „Argimütoloogiatena”, muutuvad selles kontekstis märgiliseks ja asuvad valgust heitma tema varasemale loomingule. ${ }^{5} \mathrm{Minu}$ nägemuses ongi argimütoloogia Undi kirjutuse paradigma.

Undi kirglikust huvist rituaalide, arhetüüpide ja müüdi vastu on kirjutatud palju (viimati Vaino 2019: 83-99), kuid selles teemas leidub endiselt palju segadust. Missugune on müüdi ja nõnda mõjuva realistliku kirjutuse vaheline seos? Maarja Vaino väitel püüab Unt tuhandeid aastaid vana müüti kasutades „kahtlemata väljendada midagi olemuslikku, mitte lihtsalt müüdiga mängida”, Undi romaanide kangelaste äng on „muistne, pärit iidsetest aegadest” (Vaino 2019: 85-86). Kuid missugusest muistsest ajast ja kuidas sobitub niisugune intuitsioon Undi silmatorkavalt moodsa ja realistlikuna mõjuva ainesega? Vaino püüe võtta Undi looming kokku viitena mõne müüdi piisavalt vanale vormile või lihtsa vastandusena postmodernistlikule mängule mõjub meelevaldsena ega veena. Samuti pole võimalik taandada Undi suhet müüti tema keskse eeskuju C. G. Jungi omale, seda ka juhul, kui möönda Jungi ja tema intellektuaalsete taustade (Euroopa müüdid antiigist tänapäevani, alkeemia jne) osa Undi hariduses ja nii mõnegi teose detailides. Undi retseptsioon näitab, et selliseks üldistuseks on tema looming liiga ambivalentne, seda ei saa ilma suurte kadudeta ühendada ühegi sidusa traditsioonilise kultuurisüsteemiga. Missugune tõlgendus sellisel juhul üle jääb?

Lahenduseks võiks olla püüe näha Undi kujutatud linnakultuuri ja igapäevadiskursusi endid müüdilise maailmanägemise ilmingutena täis hilissotsialistlikule ühiskonnale omaseid ideoloogilisi fantaasiaid. Need fantaasiad läbivad kõikvõimalikke reaalsuse kihte, alates argistest esemetest, eluruumidest ja asutustest kuni religiooni ja spekulatsioonideni inimpsüühika sügavama olemuse kohta. Sellisel juhul oleks Undi kirjandusliku stiili vaatluseks kasulikum lähtuda Jungi asemel semiootik Roland Barthes'ist, eriti tema varasest strukturalistlikust teosest „Mütoloogiad”. Barthes’i (2004 [1957]: 9) eesmärk oli analüüsida prantslaste

\footnotetext{
${ }^{5}$ Ka Luule Epner (2010: 21) on leidnud, et „Argimütoloogiate” alge on juba „Sügisballis”. Üritan siinses artiklis näidata, et selle alge saab viia tagasi veel varasemasse Undi loomingusse.
} 
igapäevaelus levinud müüte, milleks pakkusid ainet ajaleheartiklid, filmid, reklaamid, etendused, näitused ja isegi keeles levinud väljendid. Müüt on Barthes’i jaoks keel, mis muudab ajaloolise reaalsuse loomulikuks, igavesena näivaks tõeks ja mida saab semiootika (Barthes’i kasutuses semioloogia) meetoditega rangelt analüüsida. Müüt toimib ökonoomselt, taandades loomuldasa suhetel põhinevad fenomenid lihtsustatud ja püsivatele kujudele (nt armastus, naiselikkus, mehelikkus kui muutumatud substantsid) (Barthes 2004 [1957]: 271). Liikumine harilike tähistuspraktikate juurest müüdi valda toimub, kui tavalisi, denotatiivseid märke hakatakse tõlgendama nende konnotatiivsest, laiemast ühiskondlikust funktsioonist lähtuvalt ehk liigutakse objektide äratundmise ja neile pelga osutamise juurest kultuuriliste seoste ja väärtushinnangute keeruka põiminguni (Hall 2018: 37). Selles põimingus, milles eri sotsiaalsetel gruppidel on vastavate kultuuripraktikatega erinev suhe, loob müüt keset neid vastuolusid täieliku silmanähtavuse ja õndsa selguse mulje, pakkudes end välja ainumõeldava ja kõigile kehtiva tõena mingi sotsiaalse nähtuse kohta (Barthes 2004 [1957]: 271, müüdi sarnasuse kohta poliitilise ideoloogiaga vt ka Lévy-Strauss 2012: 97).

Barthes'i hoiak on kriitiline ja metodoloogiline, samal ajal kui Unt kirjutab argimüütidest vabalt, isegi meelisklevalt. Kriitilisi märkusi selle mõiste alla kuuluvate nähtuste kohta (mis võivad olla nii erinevad nagu „elektripirn”, „,iseseisvus”, „jahimees”, „Jõgeva” jne) leidub ka Undi lühitekstides, aga neid ei esitata lugejale normatiivselt (st kuidas asjad peaksid olema, mis on näiline ja mis tegelik). Mõlemat ühendab tähelepanu kujutiste detailidele ja vormile, nende mitmekülgsele ning tihti petlikke ihasid ja kujutelmi tekitavale funktsioonile kultuuris. Kui aga Barthes'i eesmärk on argimüüdi põhiteemad demüstifitseerida, siis Unt pigem võimendab neid stiliseerivalt ning kasutab oma teoste ainesena. Nagu alljärgnevas põhjalikumalt selgitan, jääb Barthes'i mõttes müüdiline maailmatunnetus Undi teostes kahetisse rolli: oma realistlikkusega tekitab see lugejates nauditava ahhaa-elamuse, ent kannab endas ka kriitilist võõritust. Undi teoste süžeid struktureeriv müüdiline impulss on leitav juba lause tasandilt (vt ka Kõiv 2005b: 488) teatava rõhutatud tüüpilisusena, mida üritan näidata artikli järgmises peatükis. Seejärel vaatlen lähemalt jutustusi „Räägivad” ja „Kui me surnud ei ole, siis elame praegugi”, jälgides realistliku kujutamise ja selle iroonilise õonestamise vahekorda. Olen valinud need kaks teksti kirjandusliku kvaliteedi, kuid ometi neile osaks saanud vähese akadeemilise vastukaja pärast. Autor on mõlemad teosed viimistlevalt ümber kirjutanud ja uuesti välja andnud, mistõttu võrdlen ka erinevaid variante, et jälgida Undi poeetilise ideaali muutusi. Artiklit kokkuvõtvas arutluses püüan oma tõlgendustega vastata korduma kippuvatele küsimustele Undi kirjutiste modernismi ja postmodernismi kohta.

\section{Tüüpilisuse esiletõstmine ja võõritusefekt Undi proosas: lause tasand}

Luule Epner (2010: 21-27) on osutanud, et Undi kesksel poeetilisel võttel, mille mikrotasandit siin kirjeldama hakkan, on palju ühist Bertolt Brechti võõritusefektiga, ning toonud näidetena eelkõige „Sügisballis” jutustust katkestavaid ja võõritavaid 
entsüklopeedilis-teaduslike faktidega täidetud tekstilõike. See võte intensiivistub Undi hilisemas loomingus (eriti romaanides), seisnedes romaaniteksti koormamises faktidega, mistõttu käsitlen seda argimütoloogilise stseeni konstrueerimise osana. Undi poeetika seisukohalt ei ole nimelt vahet, kas ta tsiteerib rahvasuus levinud arusaamu ja kuulujutte või uusimaid teaduslikke andmeid. Teksti realistlikus mõjus on need elemendid samaväärsed. Paralleel Brechtiga on siiski väärtuslik. Brecht sedastab: „Võõritav kopeerimine on säärane, mis võimaldab objekti küll ära tunda, kuid laseb sel samaaegselt siiski võõrana näida” (1972: 232). See pisut üldsõnaline määratlus vastab Undi isepärasele lausetüübile, mida võib leida kõikidest tema loomingu perioodidest ja mis tabab lugejat omalaadse välgusähvatusena teiste, tavalisemate lausete vahel. Toon selle kohta neli näidet, milles tõstan võtmelise koha sõredana esile:

Eemal tukkus üks naine, veel eemal üks mees, kaks nolki vahtisid lahtisest aknast öösse. Olen veidi purjus. Jürka ja Väino tirisid mu kaasa. Orkester mängis tangosid. Tango kehastab meie salajasi unistusi. Kardinad lehvisid tuules. See on nii ilus. (Unt 1967: 9)

Kõik olid oma tööga ametis nagu inimesed mujalgi sel tavalisel päeval (naised sünnitasid, sõjamehed sõdisid, põllumehed tegid he in a) (Unt 1974: 118).

Laura elas kõige ülemisel korrusel. Tema ukse lähedal šahtis ulgus tõusev ja langev lift. Õhus oli hiiresita ja toiduainete lõhna. Redel viis koridorist katusele. Pätid ronisid seda mööda üles. Nad karjusid oma segaseid hüüdlauseid, kui läksid katusele oma salatoiminguid tegema. Ilmselt oli neil seal mingi platsdarm. Ki n d l a s t i tegid nad seal taeva all midag i mehelikku. (Unt 1979: 26)

Millest siis kõneles öises hüljatud baaris too kahekümne kuue a stane keemiainsener? Muidugi sellest, et neiu talle meeldib, meeldib kui naine, meeldib talle kui mehele [---]. (Unt 1985b: 236)

Nendes näidetes hakkab silma kirjeldatava stseeni või objekti rõhutatud tavalisus. Undile on iseloomulik, et olukorra ettearvatavus tuuakse lugejani kohati ilmselgete retooriliste rõhutustega (nt kolmandas näites „kindlasti”, neljandas näites lugeja reaktsiooni ennetav „muidugi”). Esimeses näites torkab silma peategelase jutustusse põimitud (siirdkõnelisuse poole kalduv) lause „Tango kehastab meie salajasi unistusi”. See mõte ei kuulu peategelasele Ennule, vaid pigem implitsiitsele jutustajale, kelle kõnele teose avaleheküljel sujuvalt üle minnakse. Ladus siirdkõneline üleminek tegelase vaatepunktilt umbisikulisele, kui räägitakse mingi ebamäärase „meie” nimel, on Undi stiili põhikomponent. See esineb juba tema esimeses romaanis „Hüvasti, kollane kass” (1963), mille peatükk „Ema ja poja dialoogi päev” (mis on pealkirjanagi selgelt võõritav, tehniline või „teoreetiline”) algab lõiguga: 
Kevad oli inimeste silmis, suudes ja veres. Õhtuti seisid e mad valgustatud akendel ja ootasid oma tütreid, kes tulid sinisest ööst, nägudel kummaline rahu. Oi, kui raske on sel ajal üksi olla! Verine taevas värvib õhtuse jääkirmetise ja veel raagus puud heidavad vaevalt märgatavaid varje. (Unt 1985a: 106, minu sõrendus - I. O.)

Tegemist on ühelt poolt romantilises kirjandustraditsioonis levinud lüürilise vahemärkusega, mis kehtestab algava peatüki meeleolu, teiselt poolt mõjub teine lause ootamatult liialdatult ja teatraalselt. Loodud on hüperboolne nägemuslik olukord, mis üldistatakse igal kevadel toimuvaks sündmuseks. Mingi spontaanne väide - nt tango olulisusest, kevadel toimuvatest salapärastest sündmustest -, mille lausuja pole sugugi selge, ennetab lugeja reaktsioone ja esineb loo enesestmõistetava uskumusliku taustana. Lause ise võib varieeruda mänglevalt müüdilisest, nagu viimases näites Undi debüütromaanist, kuni selliseni nagu „Sügisballis” Laura (või jutustajahääle - see jääb lõpuks selgusetuks) väide pättide „mehelike tegude” kohta, mis kätkeb tervet mikrouniversumit koos selle ajaloolise konteksti, sotsioloogiliste probleemide ja ajastu mehelikkuse ideaalidega.

Need laused pakuvad suurt lugemisnaudingut ka eraldiseisvalt, koosnedes sellistest lihtsalt ära tuntavatest märkidest nagu kõigile magalaelanikele tuttavad pättide teod ja öösiti baarides aset leidvad dialoogid, kuid tõstavad samal ajal oma objekti liiga reljeefselt esile, selleks et lugeja saaks neist häireteta üle liikuda. Undi looming on omamoodi paralleel Brechti teadusajastu teatrile, iselaadne „teadusajastu proosa”, milles uuritakse ühiskonnas ringlevaid hoiakuid, müüte ja käitumismustreid. ${ }^{6}$ Argimütoloogiline materjal - tango, pättide teod magalate katustel, tütarde kojuootamine kevadöödel - saab tekstide ülesehitavaks osaks, neid ei demütologiseerita. Undi teostele ongi omane see, et kujutatavale reaalsusele ei anta hinnanguid, vaid tähtsam on kehtestada fiktsionaalne maailm, mis haakuks võimalikult paljude argimüüdiliste kujutelmadega. 1980. ja 1990. aastatel hakatakse aga kurtma Undi huvi ja ühtlasi tema teoste ainese nihkumise üle ühiskonna perifeeriasse (vt Undusk 2016 [1986] ja Hennoste 2003 [1993]). Järgmiseks analüüsingi Undi 1984. aastal ilmunud jutustust „Räägivad”, mis just niisuguse hinnangu osaliseks sai, ja avan kaks eri viisi, kuidas see nüüdisajal jätkuvalt oluline teos on loetav.

\footnotetext{
${ }^{6}$ Sellest võib tuleneda ka sotsiaalteadlaste, nagu Marju Lauristini (2010 [1978]) ja Rein Ruutsoo (2010 [1979]) elav huvi Undi teoste vastu; vt ka Ivo Heinloo (2010: 103) märkust „Sügisballi” retseptsiooni multidistsiplinaarsuse kohta. Siin on jälle kohane paralleel Barthes’i „Mütoloogiatega”. Barthes uuris semioloogia meetoditega, kuidas müüdid kui sekundaarse modelleeriva süsteemi märgid kasvatavad ennast justkui tavakeele tähistajate külge (Barthes 2004 [1957]: 232-236) ja moodustavad uue loomulikustatud reaalsuse. Tema eesmärk oli see loomulik suhe nähtavaks muuta ja läbi lõigata. Unt tegeleb samuti nende müüdimärkide tavakeeles tuvastamisega, kuid esitab neid märke silmatorkava tundlikkusega, kasutades nendes peituva müüdilisuse naudingulist aspekti.
} 


\section{Raamjutustuse mõju realistlikkusele: „Räägivad"}

Undil on jutustusest kaks varianti. Viitan lugu tutvustades teisele variandile, mis ilmus raamatus „Räägivad ja vaikivad” (1986), hiljem kirjeldan kahe versiooni erinevusi.

„Räägivad" on lugu kontoris sekretärina töötavast Eerikast, tema perest (abikaasa ja tütar) ja kolleegidest. Teos algab kaldkirjas sissejuhatusega, mis toimib ülejäänud, tegelaste otsekõnes esitatud loo raamjutustusena. Sissejuhatuses on kujutatud abstraktset ooteruumi, milles hulk inimesi maha istuvad ja vestlemist alustavad. Kaootiliselt alanud vestlusest hakkab välja joonistuma peategelase Eerika lugu, mida edaspidi teised tegelased (taksojuht, Eerika abikaasa, kolleegid, naaber Sirje jne) vahetult kommenteerivad: kõik saavad sõna otse, ilma jutustajahääle sekkumiseta, ja selline vorm lähendab teost draamakirjandusele. Sündmustikus eristub keskne intriig, milleks on Eerika õhtune kohtumine teda hirmutava taksojuhiga ja hiljem toimuv väljasõit metsa, mille asjaolud lópuks segaseks jäävad. Jutustuses on teisigi väikeseid lugusid, mida eri tegelased avavad monoloogidena, kuid nende seos põhilise süžeeliiniga on nõrk, üksiktegelaste mõtisklused ja arvamusavaldused on suhteliselt autonoomsed. Jutustuse „Räägivad” keskne ja uuenduslik vormitunnus ongi narratiivi hajutamine tugevalt subjektiivsete, argistest pihtimuslikeni varieeruvate vaatepunktide vahel, mida ei seo kokku eksplitsiitne jutustaja. Argimütoloogiline kihistus avaldub tegelaste konglomeraadis: direktor, asedirektor, sekretär ja taksojuht on juba tavaliseks muutunud ametid, mida (eriti taksojuhi oma) ümbritseb siiski kohatine salapärasuse oreool. Absurdsuseni viidud hirm taksojuhi ees on müüdilise motiivi hea näide ning see võimaldab Undil välja arendada huvitava ja realistliku karakteri, kes müüdi objektina kõneleb ise tegelasena vastu.

Teose alguses kutsutakse kõiki üles sõna võtma: „Noh, kas hakkame peale, kas hakkame pajatama, jutustama? - Eks me ju hakka rääkima?” (Unt 1986a: 6) Kõneluse ärakuulamiseks on aga omad tingimused, mis selguvad, kui „pahased hääled” kaebavad: „Ei maksa kohe alguses laiali valguda!” (Unt 1986a: 7) Anonüümsetel häältel on tekstis oluline funktsioon, nad võivad kutsuda üles kõnelema, näiteks nagu Eerikat: „Me tunneme ära. - Sa ei saa meid petta. - Hakka rääkima. - Me ootame." (Unt 1986a: 7) Kuid nad võivad ka vaigistada, näiteks öeldes äsja sisenenud naisele, kes hakkab oma abielu lugu jutustama: „Jätke järele! - Täna ei ole teie kord. - Ärge segage! - Olge ometi vait! - Eerika, räägi edasi, mis juhtus!” (Unt 1986a: 37) Jutustuse „Räägivad” vorm näib jäljendavat avalikku ruumi, milles igaüks võib sõna saada, kui see vastab meelelahutuslikkuse kriteeriumidele ning tundub piisavalt põnev ja erutav (selles näib peituvat ka teose üks kriitiline aspekt: avalikkust huvitab peamiselt klatš, mitte inimeste mured). Niisugune vormiline omapära võimaldab kaht peamist, kuid teineteist välistavat tõlgendamisviisi, mida järgmisena kirjeldan.

Ühe arusaama kohaselt (nt Undusk 2016 [1986]; Hennoste 2003 [1993]; Ross 1985) kuulub „Räägivad” Undi postmodernistlikku perioodi, mil tema loomingu põhialuseks on teised tekstid, pastišš ja mäng. Nii tundub „Räägivad” sarnane eelkõige Undi järgnevate teostega, nagu "Öös on asju” ja „Doonori meelespea” (mõlemad ilmusid 1990, kirjutatud 1980. aastatel), ning selle lugemismuljes domi- 
neerivad teksti (näiliselt) anarhiline, keskmetu häälte vaheldumine ja süžee lõpliku tõe pideva käestlibisemise kogemus. Pärast seda, kui Eerika on traumeerivat õhtut kirjeldanud, annab taksojuht toimunust hoopis teistsuguse versiooni, seejärel esitab kolmanda perspektiivi naaber Marju jne. Eri märkide paljususest ja vaheldumisest tuleneb representatsiooni ehk rääkimise enda rõhutamine ja tekstuaalse mängulisuse mulje. Senise retseptsiooni keskendumine teosele kui fragmentide kogumile ja omavahel üksnes lõdvalt seotud häälte polüfooniale on paratamatult mõjutanud ka teose realismi ambitsiooni mõistmist. On ju fragment loomuldasa iseseisev tekstiühik, mille tähendus ei sõltu tervikust. Seega tõlgendab nn postmodernistlik vaatenurk tegelaste repliikide vahetumist killustava tegurina. Näib, et „Räägivad” kujutab igasuguse sidusa ja kognitiivselt selge kõneluse võimatust. Vähemalt sellise kõneluse, mis jõuaks kas moodsa linnaelu ja erinevatest sotsiaalsetest klassidest inimeste töiste läbikäimiste hõlmava kujutuseni (ehk realistliku representatsioonini) või ka teksti süžee üheselt võetavuseni: mis juhtus ikkagi väljasõidul metsas, kas Eerika pettis oma meest jne? Selles mõttes kukub teos läbi, et see näib olevat irooniline artikli sissejuhatuses määratletud realistliku kirjutuse peaeesmärgi suhtes: moodustada piisavalt rikkaliku materjali toel ajaloolist totaalsust hõlmav kujutis. Seda täheldati juba teose esmatrüki retseptsioonis: „Undi viimase raamatu keskseks sündmustikuks on see, et midagi ei juhtu. Kõik ainult räägivad." (Ross 1985: 368) Kristiina Ross seostabki kõik süžee sündmused teose vormist tuleneva irooniaga: „Sest isegi kui Eerika või tema mehega juhtunuks midagi, poleks sel erilist tähtsust olnud. Tähtis on ainult rääkimine, mitte elamine.” (1985: 368) Ja lõpetab tõdemusega: „Unt lihtsalt kirjutab ega püüagi mõtestada ning sümboliseerida" (Ross 1985: 369).

Kuid jutustust „Räägivad” on võimalik lugeda ka vastupidisel moel: häälte paljusus ning vaheldumine ei ole loetav ainuüksi iroonilisena (olemine võrdub lõputu lobisemisega), vaid ka metonüümilisena, moodustades niimoodi uue keskkonna representatsiooni. „Räägivad” ei ole sel juhul hajutatud keskmega tekstuaalne mänguväli, vaid kujutab kõigi mimesis'ele omaste vahenditega kindlat sotsiaalset tegelikkust, mida võiks nimetada moodsaks, kommunikatsioonitehnoloogiate vormitud avalikkuseks. Undi tekst mõjub 35 aastat hiljem väga ajakohasena just selle (pseudo)avalikkuse mudeli tõttu, mis moodustub läbisegi rääkivatest häältest ja meenutab interneti, eriti sotsiaalvõrgustike dünaamikat. Uuele, kehatule ja virtuaalsele reaalsusele vastavalt puudub Undi teoses ka keskne jutustajahääl, mis sündmustest suuremat ülevaadet omaks: sõna võib võtta vabalt valitud hetkel igaüks, kes parasjagu soovib ennast väljendada, ja seda hoolimata vahelesegamisest ja vaigistamisest. Kuid Undi jutustuse „kõlakambrilikel” aruteludel on läbiv teema - meeste ja naiste vahelised suhted töökohtades, ahistamine ja võimumängud -, mis moodustab teksti psühholoogilise või sotsiaalse sisu. Selle teemavaldkonna juurde jõuab lugu justkui märkamatult, sissejuhatavaks kohaks on Eerika remark, mis osutab omaaegsetele soostereotüüpidele: „See võib tunduda naljakas, ent sek retär pe ab he a välja nä g e m a. Seda öeldakse kõikides käsiraamatuteski. S e kr e tä ri m e eld i v, n a i selik väljanägemine mõjutab ühelt poolt šefi enesetunnet, teiselt poolt aga avaldab soodsat mõju külastajate meeleolule." (Unt 1986a: 23-24, minu sõrendus $-I$. O.) 
Alates tsiteeritud lõigust hakkavad kuju võtma kohusetundliku, kuid isepäise Eerika töökollektiivisisesed suhted: ametlik ja distantseeritud direktor ihkab salaja Eerikaga lähedust; asedirektorile meeldib flirtida; tagasihoidlik katlakütja on salaja Eerikasse armunud; koristaja peab madalama ametikoha tõttu nii mõndagi taluma. Lisaks esineb väiksema tähtsusega tegelasi, nagu madalapalgaline töötaja, uurija ja varustaja, kelle rollid on pigem episoodilised. „Räägivad” on repliikide hüplikkuse tõttu pigem nõrga narratiivsusega teos, metonüümiline või realistlik lugemisviis tõstab aga rohkem esile häirivad sündmused, mis muidu jäävad teksti isepärase poeetika varju. Nendeks on kassapidaja räägitud lugu öisest autosõidust Pambergi ja Seerupiga, kes neiut vägistada püüavad ja seejärel pimedale tänavale maha jätavad (Unt 1986a: 41-43), ning koristaja vette lükkamine väljasõidul (Unt 1986a: 66). Mõlemad on traumeerivad ja afektiivselt laetud sündmused, mis moodustavad koos taksojuhi-intsidendiga mõnes mõttes teose faabula, mida tegelaste ülejäänud repliigid implitsiitselt kommenteerivad: mis on valesti meeste ja naiste suhetes? Mis toimub öistel tänavatel taksodes ja päise päeva ajal ettevõtete väljasõitudel? Kuidas inimesed neist asjadest räägivad, kuidas nad neid välja vabandada püüavad?

Jutustuse teise versiooni põhiteksti ümbritseb napp, selgelt loo raami funktsiooni täitev kirjeldus tammepuust ustega koridorist, milles kõlavad loo osaliste hääled. See on üsna abstraktne ruum, milles toimuvat edastatakse kaldkirjas, draamateksti remargi vormis. Mõnikord kostab selles jutustusse lõikuvas vahealas orelimäng, mõnikord valitseb vaikus. Samuti laulab teise versiooni lõpus kukk ja hiiglaslike akendega ruumis lendavad tuvid. 1986. aasta variandis on kokku seitse niisugust kaldkirjas vahemärkust. Raamjutustus on küll ka esimeses versioonis, kuid antud üksnes paari lausega teksti alguses ja lõpus. Kuigi nende vahemärkustega on Unt teost ümber kirjutanud minimaalselt - lisandunud on ainult poolteist lehekülge teksti -, mõjutavad lisandused siiski tähendusdünaamikat. Raamjutustus hakib lugu ja katkestab vahepeal tekkima hakanud realistliku representatsiooni mõjususe. Jutustust ennast lugedes võib kergelt neelduda selle süžeesse ja intriigidesse, sest see kujutab realistlikult praeguseks tavaliseks muutunud töökeskkonda ning avalikku suhtlusruumi. Kaldkirjas remargid tuletavad aga pidevalt meelde, et tegemist on vestlusega, mis leiab aset irreaalses ruumis, ning kogu kõnelus omandab sellega võoritava, teatraalse varjundi, mis ei lase loo sündmusi täiesti tõsiselt võtta. See lubab oletada, et teine versioon süvendas veelgi muljet, mida näitlikustab Kristiina Rossi kriitiline arvustus: Unt ei tegele millegi olulise kujutamisega, kõik üksnes lobisevad. Erinevus kahe versiooni vahel on väike, kuid nihutab jutustuse tähendust kergelt müüdilisuse, mitterealistlikkuse poole, kujutades võimalikku lõputa ja alguseta kulgevat kõnelust abstraktses ruumis. See võib olla üks põhjus, miks „Räägivad” on Undi teoste hulgas alahinnatud ja näis omal ajal „lõdvana”: teose realistlik potentsiaal avaneb alles tegelikkuse märksa virtuaalsemaks muutumise ajastul, kui suhtlustavad muutuvad Undi kujutatud kõneluste ruumile vastavaks. 


\section{Isiklikelt saatustelt müüdile: „Ja kui me surnud ei ole, siis elame praegugi"}

Jutustuse „Ja kui me surnud ei ole, siis elame praegugi” (edaspidi JKMS) esimene versioon valmis kevadel 1973 ja ilmus samal aastal ajakirjas Looming (nr 11-12, vt Unt 2009), teine versioon ilmus raamatus „Must mootorrattur” (1976, vt Unt 1985b). JKMS-i teine variant on palju jõulisemalt ümber kirjutatud kui „Räägivad” ning kehtestab selgelt müüdiliste tunnustega fiktsionaalse maailma ja vastava lugejahoiaku. Selle nihke illustreerimiseks võrdlen järgnevalt mõlema versiooni esimest peatükki.

Algvariant on lugu linnas elavast perekonnast, mille liikmeteks on ema Salme Volt, isa Julius Volt ja poeg Hannes Volt. Nende ellu ilmub salapärane 17-aastane tüdruk Maria, kes osutub pereisa endise naise tütreks. Juliusel oli pärast (Teist maailma)sõda suhe Annaga, kelle isa oli saksa sõdur, mistõttu Juliusel tekkis omal ajal Annaga armusuhte pärast töö juures probleeme. Maria välja ilmudes tekib armukolmnurk: poeg Hannes armub Mariasse ja abiellub temaga, ent pulmaõhtul põgeneb isa Julius koos Mariaga rituaalse pruudiröövi käigus, satub Mariat nähes ebastabiilsesse seisundisse, talle meenub Anna ning meeltesegaduses sõidab ta tee peale vastu tulnud Hannesele otsa. Ümberjutustatuna banaalselt mõjuv süžee on aga vaid karkass Undi intertekstuaalsele mängule ja tegelaste siseelu peenele kirjeldusele. JKMS-i esimene versioon algab pooleleheküljelise meenutusega Hannese lapsepõlvest, seejärel tutvustatakse lugejale teisi tegelasi, kes on alati tegutsemas mingis kindlas situatsioonis (Salme ja Julius kodus üksildases öises korteris, Hannes baaris baaridaamiga flirtimas). Lugeja saabki esimesest peatükist kolme peategelase napid, kuid realistlikult detailsed portreed, eriti Hannesest, kes üritab olla moodne noor inimene ning on enda jaoks üles korjanud uue, lääneliku efektiivsuse ideoloogia:

„Minu otsekohesus ja avameelsus,” rääkis Hannes Volt kunagi ja kuskil, „pole lihtsalt lobisemine. Või edevus. See on uus elustiil, mis USA ülikoolides ja vabrikutes ammu omaks on võetud. Lugesin sellest hiljuti, et seda nimetatakse „uusaususeks”. [---] Kiirus on kõik, ka suhetes. [---] Kes suhtleb kiiremini, suhtleb rohkem. Kes suhtleb rohkem, suhtleb paremini. Kes suhtleb paremini, see töötab paremini." (Unt 2009: 287)

Samal ajal elab Hannes läbi hingelist kriisi ja otsib lähedust baaridaam Leaga, mis aga kuhugi ei vii. Enim muljet avaldavas tekstikohas kujutab Unt purjus ja frustreerunud Hannese Leale suunatud monoloogi, millele aga neiu midagi ei vasta (Unt 2009: 284). Isa Julius Voldi elu kulgeb rohkem minevikus: „Kell tiksus, nagu oli tiksunud terve elu. Kogu elu, üle viiekümne aasta oli aeg voolanud, tegemata ainsatki pausi." (Unt 2009: 285) Ta meenutab endist kallimat Annat ja kujutleb, kuidas elu oleks võinud teisiti minna. Salme Volti on avapeatükis kujutatud ehk kõige skemaatilisemalt, kui ta käib öösel vett joomas ja kummardub magava poja kohale. Kolme peategelase kõrval toob Unt esimeses peatükis sisse pärimuse huntide ja libahuntide

${ }^{7}$ JKMS-i eri variantide napi analüüsi pakub Tiit Hennoste (2009: 378-380). 
kohta. Ühes episoodis pääseb kuumal suvepäeval napilt hundi käest väike kutsikas. Peatüki viimane episood kirjeldab noort naist öösel laudas surma ootamas. Neiu on „kõik õigused kaotanud” ja „maailmas ihuüksi” (Unt 2009: 289). See on muidugi vihje libahundiks käimisele. Neiu ootab, millal „läbi pakaseauru astuvad sisse need, kes on tema nägu ja tema kujuga, aga ometi nii lõpmatult võõrad. Ta ootas hetke, millal inimesed tema juurde tulevad." (Unt 2009: 290) Ühes meenutuslikus episoodis peab noor Julius pimedas metsas hunte kuulatama (Unt 2009: 280). Niisugune rütm jätkub jutustuses edaspidigi: tegelaskujude realistlikke kirjeldusi katkestavad lühikesed ekskursid müüdilise pärimuse juurde. Oluline on ka filosoofiline arutlus juhuse ja paratamatuse üle, mis on vahendatud pereisa Juliuse teadvuse kaudu. Ta on ametkondadelt palunud abi poja autoavarii asjaolude klaarimiseks. Ta nendib, et poega oleks võinud lihtsalt karistada, ,[k]uid mingi mehhanism töötas nagu iseenesest ja seadis maailmas korra jalule. Julius Volt ei olnud vaimustuses ei endast ega enda käivitatud mehhanismist." (Unt 2009: 281) Hoolimata teosesse fragmentaarsust loovatest põigetest müüdilise pärimuse juurde valitseb JKMS-i algversiooni esimeses peatükis suhteliselt realistlik tasakaal väljaarendatud karakterite ja müüdilise materjali vahel, mis kohati lugu katkestab. Need on hoitud pigem eraldi nagu kaks eri valdkonda: müüdiline universum liigub perekonnalooga paralleelselt ja heidab sellele halvaendelist varju.

Teine versioon ei alga episoodi või meenutusega mõne tegelase elust, vaid lühikese lõiguga, milles perekonda on tutvustatud lausa äärmuseni skemaatiliselt, peaaegu igasuguse individuaalsuseta:

Elas kord kolmeliikmeline perekond: isa, ema ja poeg. Vanemad olid u mbes pool sajandit vanad, poeg aga umbes veerand sajandit. Nende kodu oli keskmise suurusega eramajas. Ka ise kuulusid nad keskklassi. Isa töötas peavalitsuses, ema oli kodune, poeg lõpetas paar aastat tagasi keemia stuudiumi ja oli inseneriks ühes suures ettevõttes. (Unt 1985b: 234, minu sõrendus - I. O.)

Vormeli „Elas kord” kasutamine, samuti viited keskmise suurusega eramajale ja keskklassi kuulumisele on autoparoodilised ja loovad müüdilise fiktsioonimaailma, andes oma hüperboolsusega ühtlasi võtme ülejäänud teksti lugemiseks. Keskseks muutuseks on pärisnimede asendumine üldnimedega: Hannesest on saanud poeg, Juliusest isa, Salmest ema, Mariast tüdruk, sekretär Elmar Rosenbergist lihtsalt ökonomist jne. Pärisnimede kasutamine eeldab proosakirjanduses tavaliselt, et tegelaste identiteedid on piisavalt lahti kirjutatud ja neil on midagi, mida Madis Kõiv (2005b: 467) oma käsitluses nimetab tegelaste individuaalseks ajaks. Individuaalne aeg on aluseks tegelaste saatustele (elulugu kui tähenduslik tervik), mis on omakorda olnud üks realistliku representatsiooni kriteeriume varasemas romaanitraditsioonis, mida Undi looming dekonstrueerib. Hea näide selle kohta, kuidas Undi jutustuse eri versioonide tegelase individualiseerituse aste lahkneb, on purjus Hannese ja baaridaami stseen esimeses peatükis. Kui algvariandis on seda kujutatud Hannese pika monoloogina, mis annab põhjalikult aimu noormehe vaevatud ja samal ajal agressiivsest vaimsest olekust (Unt 2009: 284-285), siis teises versioonis on selle asemel lühike 
kokkuvõte kõneldust „, elles k ohas ja tollel tä naval, ja et ta on siis seda ja seda mõelnud" (Unt 1985b: 236-237, minu sõrendus - I. O.).

Samuti on teises versioonis poja käitumise kirjeldusele lisandunud hinnangulisus, mis pärsib lugeja empaatilist suhtumist temasse. Näiteks kirjeldatakse noore Hannese kommet kujutleda, kuidas salajane jõud toob tema juurde (ja voodisse) kõik ihaldusvärarsed naised, keda ta linna peal märkab. Algversioonis sisaldab see lõik ohtralt detaile (mainima peab salasõna plötzlich ${ }^{8}$, nõiduse käivitab Hannese portfelli sanga neet) ja osutab levinud, ent ikkagi intiimsele seksuaalfantaasiale, milles noormeest ei kurnaks flirdirituaalid:

Nad ei esitaks küsimusi: miks? kas? kus? mis saab edasi? Nad ei vajaks pehmeksrääkimist, komplimente peale nende, mis armuakti juures vajalikud või lihtsalt spontaansed, nad ei nõuaks muret tagajärgede pärast. Nad oleksid armunud ilma mingi Hannesepoolse vaevata. Aga nad ei oleks prostituudid, vaid tavalised naised. (Unt 2009: 282-283)

Teises versioonis on poja fantaasiat kujutatud pigem jõhkrana, mis ei võimalda eriti empaatiat: „Pojal oli kooliajast peale ülbe komme vaadata tänaval naisi ja kujutleda end omamas sellist võlujõudu, mis oleks tema poolt väljavalitud naised toonud tema voodisse ilma mingi temapoolse pingutuseta" (Unt 1985b: 235, minu sõrendus - I. O.).

Neid muutusi võib mõista personaalsete teadvuste realistlikust kujutamisest ja teistega kõrvutamisest loobumisena ning lihtsama, skemaatilise ja väljastpoolt lähtuva, tihti ka hinnangulisema perspektiivi andmisena. Heaks näiteks on Juliuse mõtete kujutamine öises korteris. Esimeses variandis häirib Juliust kella vali tiksumine, mis langeb kokku ta südamelöökidega: „Olen ma südamehaigeks jäänud, mõtles Julius Volt ennast kuulatades. Teda tabas hirm ja ta ei liigutanud ennast enam.” (Unt 2009: 285-286) Teises variandis ütleb jutustaja lihtsalt: „Hirm südamehaiguse ees, mida tekitas kella ja südame resonants, oli pigem formaalne, kätteõpitud. Isa oli tahtetu, lõtv, vana ja ootel." (Unt 1985b: 237) Tegelaste passiivseks, saatuse mängukannideks muutumise võtab kokku paratamatusele osutav masina või mehhanismi metafoor, mis on teises versioonis tõstetud esile ja vabastatud seosest mõne tegelase perspektiiviga: „Isa oli mingi relee, fotorakk, mis mitmetuhandelise kõrgepingeliini sisse lülitas” (Unt 1985b: 237). Ning jutustaja ütleb otse: „Õnnetus on meile nagu masin, mille me õigel ajal käiku laseme. Meie õigus on siin luua üks maailm ja lasta sel hävida, ehk: mina olen su sünnitanud, mina su ka tapan." (Unt 1985b: 239)

Kokkuvõtteks võib täheldada, et JKMS-i teise variandiga on Unt nihkunud individuaalsete tajude ja mõtetega tegelaste realistlikult kujutamiselt skemaatilisemasse, nii et kogu realistlik impulss seisneb lugeja eeldatavas kaasatulekus visandliku ja paroodilise argimüüdil põhineva kirjeldusega keskmisest Tallinna perekonnast. Õigustatud oleks ka tõlgendus, mida ma siin pikalt ei puuduta, kuid mis lähtuks Undi arengust kirjanikuna ja käsitleks tema teoseid kui refleksioone kirjaniku rolli ja

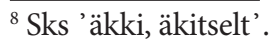


Undi stiili muutumise üle. JKMS-i teine versioon tundub sellisel juhul olevat karm allegooriline kohtumõistmine esimese üle. Isa kohta öeldud sõnad „tahtetu, lõtv ja ootel” iseloomustavad kirjaniku passiivset olekut; „formaalsed, kätteõpitud hirmud” aga väljamõeldise loojat olukorras, kus tema afektid peavad piisavalt intensiivsed olema, et väljamõeldise realistlik usutavus ei kannataks. Kahe versiooni vahelise erinevuse jälgimine ei pruugi aga tähendada keskendumist ainult Undi loomepsühholoogiale (mis on omaette ja kindlasti mitte triviaalne teema) ja teoste mõtestamist autori individuaalsete väärtushinnangute muutumise abil. See selgitab ka kirjanduses realistliku kujutamise sisemisi pingeid, mis tulenevad diskursiivsetest ja ajaloolistest seikadest. Kõige enam ehk „Tühirannast”, aga ka JKMS-i esimesest variandist on näha, et Unt on väga võimekas individuaalse karakteri teadvuse kujutaja. Kuid ta ei ehita oma teoseid üles ajas kestvale tugevate karakterite süsteemile, nagu on omane Undile eelnenud realismi traditsioonile, mille esindajad A. H. Tammsaare ja Thomas Mann olid talle olulised eeskujud. Harilikult on Undi töö lópptulemuseks teos, mis on visandliku (aga väga täpselt oma ümbrusse sobituva) tegelase ja ideaalselt valitud argimütoloogilise objektide süsteemi vaheline kompromiss. ${ }^{9}$

\section{Kokkuvõte: Unt modernisti ja postmodernistina}

Olen üritanud rekonstrueerida Mati Undi poeetikat, asetades selle keskmesse argimütoloogia kui ühe realistliku kirjutuse allika ja tekstide poeetilise ideaali. Mis on nüüdisaegne domineeriv hirm, lugu, lootus, inimestevaheline iseloomulik žest või isegi (kvaasi)religioosne hoiak, mida ühiselt ära tuntakse, aga sõnastada ei suudeta? Just selliste küsimuste peale näis Undil olevat n-ö absoluutne kultuuriline kuulmine, mida on tema loomingu põhjalikumad käsitlejad üritanud ka sõnastada. Et argimüüt võib olla realistliku kirjutuse allikas, ei tundu imelik, kui ühiskondlikku reaalsust mõista erinevatel müstifikatsioonidel põhinevana. Sellisel juhul tähendab müüdiline elunägemus midagi üsna igapäevast, suurte inimgruppide ühiseid spontaanseid reageeringuid maailmale, mille abil hoitakse alal oma minapilti. Need reageeringud ja lood, mida räägitakse, ei pruugi rangelt võttes tõele vastata ja mõjuvad paljuski reaalsust moonutavalt. Kirjanduse võimaluseks ongi sellel hetkel sekkuda, tekitada lugejas võõritust ja sundida teda ümbritsevaid näiliselt tervemõistuslikke hoiakuid

\footnotetext{
${ }^{9}$ Undi jaoks on ühelt poolt karakteritele ja teiselt poolt välisele, stseenile keskendumise kui realistliku kujutamise eri tüüpide probleem alati oluline olnud. Näiteks jutustuses „Kuuvarjutus” laseb Unt tulla minajutustajast naisel mõttele kirjeldada oma meest. Naine arutleb kirjeldamise raskuse üle, misjärel teeb jutustajast tegelane ootamatult märkuse romaani kirjutamise ja karakterite kohta: „Aga teiselt poolt: miks te peaksite teda nägema? Ega ma ei kirjuta ju ometi mõnda romaani, kus on karakterid. Ma ei armasta karaktereid. Nad on jälgid. Neid ei tahaks tuppa lasta." (Unt 1986b: 134) See on vaid üks näide paljudest, kus Unt otsesel või allegoorilisel kujul arutleb oma kirjutusviisi keskse probleemi üle: kui palju jätta oma tekstis ruumi tegelaste individuaalsetele afektidele ja lugudele, kui teksti peamine mõju tuleb kõige modernsema kultuuris ringleva tuumstseeni tuvastamisest ja tundlikust lahti kirjutamisest? Sellised kohad näitavad, kui oluline on Undi jaoks olnud kunsti ja reaalsuse vahelise suhte ning sellega seoses ka realistliku kujutamise probleem.
} 
ära tundma sellena, mis need tegelikult on - argimüütidena. Argimütoloogia ${ }^{10}$ kui kirjutuse liik oli Undi jaoks ka kompositsiooniline probleem, sest mitte iga lugu ei sobi käibivate ideoloogiliste representatsioonidega. Ideoloogilise kliima meisterlik kujutamine, mida Unt valdas, ei pruugi kokku sobida individuaalse tegelase realistliku kujutusega, mis nõuab pikemat teksti.

Tavateadvuse müüdilise päritolu kasutamine realismi allikana heidab valgust ka küsimusele Undi loomingu modernistlike ja postmodernistlike lugemisstrateegiate kohta. Undi argimüütidest võrsuv realistlikkus põhineb suuresti tsitaadilistel, umbisikulise staatusega võõritavatel fraasidel ja faktidel (vt ka Krull 1993). „Võõra sõna” kihid aga segunevad tegelaste teadvusi kujutavate tekstiosadega, luues mulje pidevalt vahelduvast ideoloogilisest kliimast, milles Undi tegelased püüavad leida oma kohta ja elada. Just see piiride ähmastumise efekt moodustab Undi teostes nn realismi stseenilise külje (vt Ojam, Tomberg 2016). Tegelaste „personaalne aeg” (kui kasutada veel kord Madis Kõivu väljendit) või saatus lahustub ühiskonnas ringlevate ebaisikuliste arvamuste, uskumuste ja hoiakute paljuses. Nii on Undi proosateoste karakterid küll romaanikirjanduse paremikuga võrreldes skemaatilisemad, kuid tegelase isiklikku identiteeti ümbritseva impersonaalse diskursuse nõtke väljajoonistamine loob Undi teostele omase realistliku efekti. Undi tegelane vaatab enda elu ja identiteeti alati kõrvalt, lugematute meediumide kaudu. Nende peegelduslike vaatepunktide pideva sujuva vaheldumise, tegelase isikliku teadvuse ja ebaisikulise diskursuse segunemise käsitlemine teose domineeriva koodina langeb kokku Undi interpreteerimisega m o d e r n i s t in a. Kõige moodsamad kultuuris ringlevad informatsioonikübemed, hoiakud ja kinnismõtted moodustavad modernistlikule paradigmale kohase eksistentsiaalse atmosfääri, milles unikaalne inimene püüab sidusat subjektiivsust alal hoida. Keskmes on teadvuse ühtsuse ja lahustumise, puuduse ja armastusevajaduse küsimused (vt nt Jaanus 1990, 1997).

Kuid Undi teoseid on võimalik tõlgendada ka tekstuaalse ja mängulisena - p o s t moder nistliku kirjandusena, nii nagu jutustus „Räägivad” tundus kaasaegse kriitika jaoks Undi varasema loominguga võrreldes liiga „lõtv” ja lobisev, olles justkui kirjanduse realistlikust ambitsioonist loobunud. Postmodernistliku tõlgenduse aluseks on olnud allegooriline tähendusloogika, mis toimib alguses enesele osutavalt ja mänguliselt, ent muutub kergelt irooniliseks ja hakkab esile kutsuma nihilistlikku lugemisviisi, mis eitab igasuguse representatsiooni võimalikkust. Nii on Undi teoste lugemise käigus alatihti jõutud momendini, kui kõik tundub olevat nali, pelk mäng jne. Olulised pole enam niivõrd inimelu eksistentsiaalsed küsimused, vaid kirjutus ise kui nauding ja aina hargnev intertekstuaalsus, mis ei suuda luua tõsist realistlikku kujutist. Selline tõlgendus on olnud liialdus, kuna ka iroonilised tekstid kehtestavad kirjandusliku maailma ning algatavad auerbachilikus mõttes järjekordset realist-

\footnotetext{
${ }^{10}$ Läbiva viitamisega argimüütidele kui igapäevareaalsuse müstifikatsioonidele ei taheta siin artiklis väita, et aines, mida tuntakse klassikalise müüdipärimusena (pühast graalist libahuntide ja Oidipuse-lugudeni), mis funktsionaalses mõttes Undi kaasaegses linnaelus käibel ei olnud, oleks Undile kuidagi vähem tähtis olnud. Ta põimis seda paljudesse oma tekstidesse ja lavastas hiljem neid klassikalisi lugusid väsimatult. Undi kui realistliku kirjaniku suurim oskus oli aga tabada juba argikäitumises endas müüdilisi skeeme, kui viimased on veel enamiku inimeste jaoks teadvustamatud.
} 
likku kujutamist, mille teemaks on näiteks suhtlusaktide läbikukkumine ja tõelise kõneluse võimatus moodsas, infotehnoloogiast küllastunud ühiskonnas.

Undi teosed pakuvad rangelt võttes alust mõlemaks. Realistlikkusest rääkimine eeldab siiski, et kujutamine on võimalik ja iroonia ei tühista kogu kriitilist diskursust. Samuti ei olnud Undi siin vaadeldud teoste ümberkirjutuste eesmärk realistliku mõju tühistamine, vaid ilmselt nende teoste muutmine ideoloogiliselt voolujoonelisemaks, ajale vastupidavamaks. Ümberkirjutuste jälgimine võimaldab näha mitte ainult viise, kuidas intellektuaalist kirjanik tuli toime oma tekstide paratamatu ebatäiuslikkusega, vaid ka vahetute ühiskondlike olude muutusi, mis väljenduvad erimeelsustes teoste vastuvõtus alates 1980. aastatest.

Tulles veel kord tagasi argimüüdi või -mütoloogia mõistete juurde, oletan, et kirjutajatee alguses, 1960.-1970. aastatel kasutas Unt sihilikult ainest, millel oli suur utoopiline tähenduspotentsiaal ning mis tagas tema teostele iseäraliku modernsuse. Aastate möödudes aga selle materjali utoopilised lubadused ja võlu kuhtuvad, mille tõttu muutus ka Undi teoste toon. Ta saavutas kirjanikuna intellektuaalse küpsuse 1970-ndate keskel, säilitades aga lõpuni huvi kõige uudse vastu kultuuris. Kuid otsustavalt muutus tema suhtumine nn argimüütide utoopilisse potentsiaali ehk lootusesse nende kõikvõimalike (enamasti tehnoloogiliste) uuenduste abil kultuuris ja inimsuhetes mingisuguse püsiva parema elu juurde välja murda. Unt nägi üsna hästi läbi ka siirdeühiskonna vaimustus- ja ootuspuhanguid ning tema hilisemates teostes valitseb skeptiline toon. Moodsa müüdi üle võib ta veel mõlgutada ja kirjutada lühikesi arutlusi, kuid see ei paku enam ainet uudseks kirjanduseks. Võib-olla suudavad viimastel aastatel esile kerkinud humanitaarteaduslikud uurimused Nõukogude Liidu ja teiste idabloki riikide argikultuuri helgematest külgedest heita uut valgust ka Undi fenomenile, võrreldes tema loomingut teiste Ida-Euroopa apoliitiliste intellektuaalide ja kirjanikega, kes tegelesid eelkõige puhta kunstiga, kuid suutsid üsna varakult läbi näha nende riikide lääne ühiskonda integreerumise illusoorsed lubadused.

\section{KIRJANDUS}

Auerbach, Erich 2012. Mimesis. Tegelikkuse kujutamine õhtumaises kirjanduses. Tlk Kalle Kasemaa. (Avatud Eesti raamat.) Tartu: Ilmamaa.

Barthes, Roland 2004 [1957]. Mütoloogiad. Tlk Mirjam Lepikult, Ott Ojamaa. Tallinn: Varrak.

Berg, Oliver 2015. Mati Undi „Tühirand” läbi fenomenoloogilise hoiaku. Bakalaureusetöö. Tartu Ülikooli kultuuriteaduste ja kunstide instituut. https://dspace.ut.ee/ handle/10062/48779

Brecht, Bertolt 1972. Vaseost. Valik teatriteoreetilisi töid. Tallinn: Eesti Raamat.

Epner, Luule 2010. Unt ja Brecht: võõritused „Sügisballis”. - Sügisball. Koost Virve Sarapik, Piret Viires. (Etüüde nüüdiskultuurist 2.) Tallinn-Tartu: Eesti Kirjandusmuuseumi kultuuri- ja kirjandusteooria töörühm, Tartu Ülikooli Kirjastus, lk 17-27.

Epner, Luule 2018. Mängitud maailmad. (Heuremata. Humanitaarteaduslikke monograafiaid 8.) Tallinn-Tartu: Tartu Ülikooli Kirjastus. 
Hall, Stewart 2018. Keelest kultuurini. Keeleteadusest semiootikani. - Representatsioon. Kultuurilised representatsioonid ja tähistamispraktikad. Koost S. Hall, Jessica Ewans, Sean Nixon. Tlk Eva Näripea. Tallinn: Eesti Kunstiakadeemia Kirjastus, lk 35-39.

Heinloo, Ivo 2010. „Sügisballi” mitmest retseptsioonist. - Sügisball. Koost Virve Sarapik, Piret Viires. (Etüüde nüüdiskultuurist 2.) Tallinn-Tartu: Eesti Kirjandusmuuseumi kultuuri- ja kirjandusteooria töörühm, Tartu Ülikooli Kirjastus, lk 102-108.

Hennoste, Tiit 2003 [1993]. Mati Unt. Mälestused ja lootused. - T. Hennoste, Eurooplaseks saamine. Kõrvalkäija altkulmupilk. Artikleid ja arvamusi 1986-2003. Tartu: Tartu Ülikooli Kirjastus, lk 256-260.

Hennoste, Tiit 2009. Piiriaeg. - Mati Unt, Kogutud teosed 3. Tallinn: Hermes, lk 369-383. Jaanus, Maire 1990. Modernism Eestis: Mati Undi proosa. - Vikerkaar, nr 4, lk 55-60. Jaanus, Maire 1997. Mati Undi „Via regia”: vorm ja praxis. - Vikerkaar, nr 1-2, lk 105-114. Jameson, Fredric 2007 [1990]. Late Marxism. London-New York: Verso.

Kalda, Maie 1976 [1969]. Mõrvaloo ümberjutustus. - M. Kalda, Kirjandusest ja kriitikast. Tallinn: Eesti Raamat, lk 68-74.

Kesküla, Kalev (koost) 2008. Undi-jutud. Mälestusi Mati Undist. Tallinn: Hermes.

Krull, Hasso 1993. Unt, jäljendamise jäljendaja. - Vikerkaar, nr 12, lk 63-68.

Kõiv, Madis 2005a. Jäämäest loobumine. - M. Kõiv, Luhta-minek. (Eesti mõttelugu 61.) Koost Aare Pilv. Tartu: Ilmamaa, lk 491-506.

Kõiv, Madis 2005b. Mati Unt: Must mootorrattur. - M. Kõiv, Luhta-minek. (Eesti mõttelugu 61.) Koost Aare Pilv. Tartu: Ilmamaa, lk 454-490.

Lauristin, Marju 2010 [1978]. Arusaamatu autor? - Sügisball. (Etüüde nüüdiskultuurist 2.) Koost Virve Sarapik, Piret Viires. Tallinn-Tartu: Eesti Kirjandusmuuseumi kultuuri- ja kirjandusteooria töörühm, Tartu Ülikooli Kirjastus, lk 109-111.

Lévi-Strauss, Claude 2012. Müütide struktuur. - C. Lévi-Strauss, Strukturaalantropoloogia. Valik artikleid. (Bibliotheca anthropologica.) Koost Marek Tamm, tlk Anti Saar. Tallinn: TLÜ Kirjastus, lk 92-131.

Ojam, Indrek; Tomberg, Jaak 2016. Stseenilise oleviku mõjujõust kirjandusliku realismi esteetikas. - Keel ja Kirjandus, nr 4, lk 281-298.

Puudersell, Eliisa 2017. M-äng Mati Undi „Tühirannas” ja „Via regias”. - Methis. Studia humaniora Estonica, nr 19, lk 112-126.

Puudersell, Eliisa 2019. M-äng Mati Undi loomingus. Magistritöö. Tartu: Tartu Ülikool. https://dspace.ut.ee/handle/10062/65263

Remmel, Taavi 2015. Mati Undi „Mõrv hotellis” metafüüsilise detektiivjutustusena. Magistritöö. Tallinna Ülikool.

Ross, Kristiina 1985. Kirjutab. - Keel ja Kirjandus, nr 6, lk 368-369.

Runnel, Hando 1980. Mati Unt ja mood (Close reading). - Keel ja Kirjandus, nr 2, lk 115-120.

Ruutsoo, Rein 2010 [1979]. Šveitser Theo planeet. - Sügisball. (Etüüde nüüdiskultuurist 2.)

Koost Virve Sarapik, Piret Viires. Tallinn-Tartu: Eesti Kirjandusmuuseumi kultuuri- ja kirjandusteooria töörühm, Tartu Ülikooli Kirjastus, lk 112-115.

Sarapik, Virve; Viires, Piret (koost) 2010. Sügisball. (Etüüde nüüdiskultuurist 2.) TallinnTartu: Eesti Kirjandusmuuseumi kultuuri- ja kirjandusteooria töörühm, Tartu Ülikooli Kirjastus. 
Undusk, Jaan 2016 [1986]. Meie Unt. Kiites ja kahetsedes. - J. Undusk, Eesti kirjanike ilmavaatest. (Eesti mõttelugu 118.) Tartu: Ilmamaa, lk 776-781.

Unt, Mati 1967. Elu võimalikkusest kosmoses. - Loomingu Raamatukogu, nr 4. Tallinn: Perioodika.

Unt, Mati 1974. Mattias ja Kristiina. Tallinn: Eesti Raamat.

Unt, Mati 1979. Sügisball. Stseenid linnaelust. Tallinn: Eesti Raamat.

Unt, Mati 1985a. Hüvasti, kollane kass. - M. Unt, Valitud teosed 1. Tallinn: Eesti Raamat, lk 14-128.

Unt, Mati 1985b. Ja kui me surnud ei ole, siis elame praegugi. - M. Unt, Valitud teosed 2. Tallinn: Eesti Raamat, lk 234-280.

Unt, Mati 1986a. Räägivad. - M. Unt, Räägivad ja vaikivad. Tallinn: Eesti Raamat, lk 5-76.

Unt, Mati 1986b. Kuuvarjutus. - M. Unt, Räägivad ja vaikivad. Tallinn: Eesti Raamat, lk 117188.

Unt, Mati 1993. Argimütoloogia sõnastik 1983-1993. Tallinn: Kupar.

Unt, Mati 1996. Vastne argimütoloogia. Tallinn: Vagabund.

Unt, Mati 2003. Sirise, sirise, sirbike. Sirbimütoloogiad 1997-2002. Tallinn: Sirp.

Unt, Mati 2009. Ja kui me surnud ei ole, siis elame praegugi. Algvariant. - M. Unt, Kogutud teosed 3. Tallinn: Hermes, lk 277-355.

Vaino, Maarja 2019. Mati Undi hämaruse poeetika. Tallinn: EKSA.

White, Hayden 1999. Auerbach's Literary History. Figural causation and Modernist Historicism. - H. White, Figural Realism. Baltimore-London: Johns Hopkins University Press, lk 87-101.

Williams, Raymond 1977. Structures of feeling. - R. Williams, Marxism and Literature. Oxford: Oxford University Press, lk 128-136.

Indrek Ojam (snd 1988), MA, Tartu Ülikooli kultuuriteaduste instituudi doktorant (Ülikooli 16, 51014 Tartu), indrekojam@gmail.com

\section{The so-called everyday mythology as a source of Mati Unt's realist poetics}

Keywords: Mati Unt, literary realism, critique of ideology, Soviet-era urban literature

The aim of this article is to reinterpret the style and rhetoric of Mati Unt's proseworks from the point of view of critique of various so-called everyday myths ("everyday mythology" also being the term title of Unt's late essay-collections). The critical praise in Unt's reception has revolved mostly around his unique ability to depict the most modern cultural trends, catchphrases and phenomena of his time. This talent of Unt has been explained by the author's deep interest in myths and Jungian psychoanalysis. I propose, however, that the key author to understand the specific equilibrium of realism and estrangement so characteristic of Unt's works, is Roland Barthes and his early book "Mythologies" (1957). Barthes' contemporary French 
consumer-society was saturated with mythical tropes, which he proceeded to deconstruct using the critical methods of semiotics. Barthes saw the stereotypes of his contemporary television and commercial world as sedating and affirming the status quo. Cultural clichés of various kinds were also crucial raw material for Unt's novels and short stories. He incorporated these materials into his works rather organically, thus achieving realistic effects, but often also overemphasised these tropes, coming close to estranging the reader. I attempt to show, through close-reading of two Unt's short novellas from his middle period - "And if we are not dead, we shall be living on" (1973) and "Talking" (1984) - how Unt constructed a realistic story-world, using various modern stereotypes, and later rewrote these stories. The article ends with a discussion of how my analysis may contribute to the debate about Unt's ambivalent place between modernism and postmodernism in Estonian literature.

Indrek Ojam (b. 1988), MA, doctoral student and junior researcher at the Department of Literature and Theater Studies in the University of Tartu (Ülikooli 16, 51014 Tartu), indrekojam@gmail.com 